\title{
Arthroscopic Repair of Type II SLAP Lesion with Bioab- sorbable Knotless Suture Anchor: Surgical Technique and Clinical Results
}

\author{
Chae-Chil Lee, M.D., Sung-Jae Kim, M.D. *, Chang-Ho Hwang, M.D.***, \\ Dong-Kyo Seo, M.D., Sang-Hun Ko, M.D.**.
}

Shoulder Service and Sports Medicine, Department of Orthopedic Surgery, Rehabilitation Medicine***, Ulsan University Hospital, University of Ulsan College of Medicine, Yonsei University*

Purpose: The purpose of this study was to evaluate the results of bioabsorbable knotless suture anchoring for isolated type II SLAP.

Materials and Methods: Fourteen patients with isolated type II SLAP underwent a surgical repair with bioabsorbable knotless anchor arthroscopically. Instability, rotator cuff tears or simple subacromial decompression were excluded. The UCLA and pain of VAS (Visual Analogue Scale), ADL (Activity of Daily Living, from the American Shoulder and Elbow Society) were evaluated and patients underwent a thorough shoulder examination at a minimum follow-up period of 2 years postoperatively.

Results: At a mean of 27.1 months follow-up. The mean UCLA score improved from 14.4 pre-operatively to 31.2 on last follow-up. The mean VAS for pain was 4.9 and on last follow-up 1.0. The mean VAS for instability was 2.6 and on last follow-up 0.5. The mean ADL was 10.4 and on last follow-up 25.0. 12 patients reported their satisfaction as good to excellent and 10 of the 14 patients returned to their pre-injury level of activity (athletics) $(\mathrm{P}<0.05)$.

Conclusion: Arthroscopic repair with bioabsorbable knotless suture anchors is an effective surgical technique for the treatment of an isolated unstable type II SLAP lesion. Overall satisfaction was only $85.7 \%$. 1 patient had severe stiffness and 1 patient had shoulder pain.

Key Words: Shoulder, Isolated unstable SLAP, Bioabsorbable knotless suture anchor.

\section{INTRODUCTION}

The superior labrum lesions was described first by Andrews et al in 1985 ${ }^{11}$. Snyder et al described the acronym superior labrum anterior and posterior (SLAP) lesion and subsequently presented their classification. Maffet et al further defined the SLAP lesions with suture anchors ${ }^{8,16}$. The current treatment is to restore stability to the biceps anchor in type 2 and 4 SLAP lesions with suture

\footnotetext{
※통신저자: Sang-Hun Ko, M.D., Ph.D.**

Department of Orthopedic Surgery, Ulsan University Hospital,

University of Ulsan College of Medicine

290-3 Jeonha-Dong, Dong-Gu, Ulsan 682-714 Korea

Tel: 82-52-250-7129, Fax: 82-52-235-2823, E-Mail: sanghunko@yahoo.com
} 
anchors that require knot tying.

But the technical difficulty of arthroscopic knot tying is challenging step ${ }^{17-19)}$. Potential loosening of knot tying cause recurrence of pain and failure of treatment. The knotless suture anchor (Mitek, westwood, MA) has the benefit that knots are not needed for fixation. Moreover bioabsorbable knotless suture anchors (Bioknotless Anchor; Mitek, Norwood, MA) has provide a good, low profile reconstruction without the added complexities of arthroscopic knot tying ${ }^{18.22)}$.

This paper reported our clinical results and technique for type II SLAP with bioabsorbable knotless suture anchor. There was no article for clinical result of type II SLAP repair with bioabsorbable knotless suture anchor in English literature $^{22)}$.

\section{MATERIAL AND METODS}

We performed arthroscopic repairs on 14 patients with type II SLAP lesion using by bioabsorbable knotless anchor from January 2003 to April 2004, and these patients were followed up for minimal 2 years. Average follow-up period was 27 months (range 24 36 months). The 14 patients consisted of 10 males and 4 females, with an average age of 20 years (range, 17 40 years). Surgery on the dominant arm was performed in 10 patients (71\%), and 4 (29\%) on the non-dominant arm. The average duration of symptom were 11 months (range 3 30 months). Patients suffered from shoulder pain, crepitation, sometimes instability. MR arthrogram is identified by linear high signal intensity on coronal oblique view in cases (Fig. 1).

The inclusion criteria are isolated SLAP
II lesion, minimum 2 year follow-up. The 14 patients selected for the study were evaluated both preoperatively and postoperative follow-up: 3 months, 6 months, 12 months, 18 months, 24 months and final follow-up (Table 1).

Shoulder function was evaluated by VAS (Visual Analogue Scale) for pain, VAS for instability, ADL (Activity of Daily Living, from the American Shoulder and Elbow Society), and $\operatorname{ASES}^{14)}$ and UCLA $^{4)}$ scores of 5 items of pain, func-

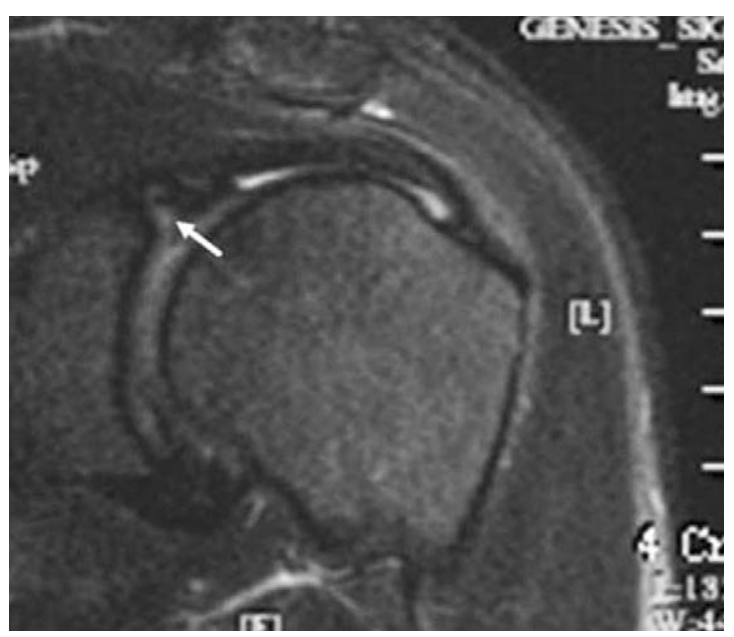

Fig. 1. Preoperative MR coronal oblique view. The arrow indicates SLAP lesion which is identified by linear high signal intensity.

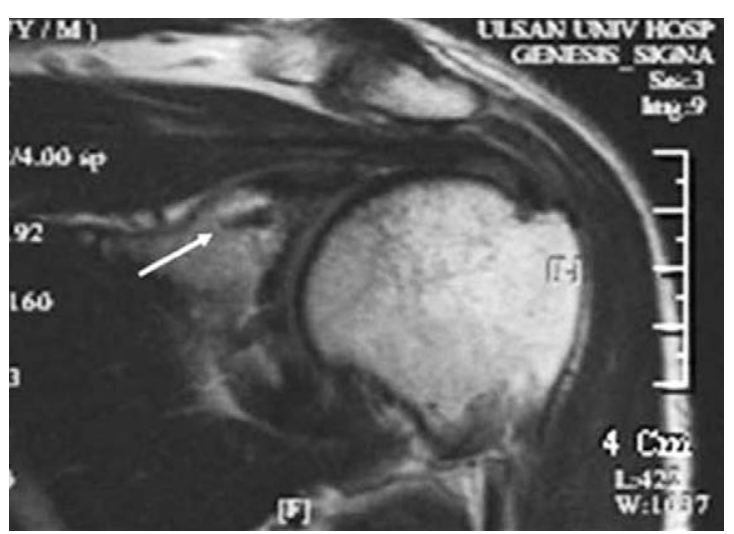

Fig. 2. Final MRI is checked, the arrow indicates inserted anchor on coronal oblique view. 
- Sang-Hun Ko, et al : Arthroscopic repair with bioabsorbable knotless suture anchor -

Table 1. Demographics of the Patients and Follow-up Results.

\begin{tabular}{cccccccccc}
\hline \hline Patients & Age & Sex & F/U & $\begin{array}{c}\text { VAS }{ }^{\dagger} \text { of } \\
\text { pain } \\
\text { (preOP) }\end{array}$ & $\begin{array}{c}\text { VAS of } \\
\text { pain } \\
\text { (postOP) }\end{array}$ & $\begin{array}{c}\text { VAS of } \\
\text { instability } \\
\text { (preOP) }\end{array}$ & $\begin{array}{c}\text { VAS of } \\
\text { instability } \\
\text { (postOP) }\end{array}$ & $\begin{array}{r}\text { ADL }^{\dagger} \\
\text { (Pre) }\end{array}$ & $\begin{array}{c}\text { ADL } \\
\text { (Post) }\end{array}$ \\
\hline 1 & 17 & M & 246 & 2 & 2 & 0 & 1 & 2 & 26 \\
2 & 18 & M & 27 & 4 & 0 & 3 & 0 & 5 & 26 \\
3 & 19 & M & 24 & 6 & 2 & 2 & 0 & 8 & 25 \\
4 & 20 & F & 28 & 4 & 0 & 3 & 1 & 11 & 28 \\
5 & 21 & M & 26 & 5 & 2 & 2 & 1 & 11 & 25 \\
6 & 21 & M & 29 & 4 & 2 & 3 & 0 & 14 & 20 \\
7 & 23 & M & 32 & 5 & 1 & 3 & 1 & 12 & 22 \\
8 & 26 & F & 28 & 6 & 2 & 3 & 1 & 8 & 28 \\
9 & 27 & M & 26 & 5 & 2 & 3 & 1 & 14 & 24 \\
10 & 28 & M & 31 & 5 & 3 & 1 & 0 & 15 & 21 \\
11 & 31 & M & 30 & 5 & 1 & 3 & 0 & 12 & 29 \\
12 & 31 & M & 30 & 7 & 2 & 2 & 0 & 16 & 25 \\
13 & 32 & F & 36 & 6 & 1 & 2 & 1 & 10 & 29 \\
14 & 40 & F & 25 & 5 & 5 & 4 & 0 & 16 & 23 \\
Average & 20 & M10/F4 & 27.1 & 4.9 & 1 & 2.6 & 0.5 & 10.4 & 25 \\
\hline
\end{tabular}

${ }^{\dagger}$ Visual Analogue Scale

${ }^{*}$ Activity of Daily Living, from the American Shoulder and Elbow Society

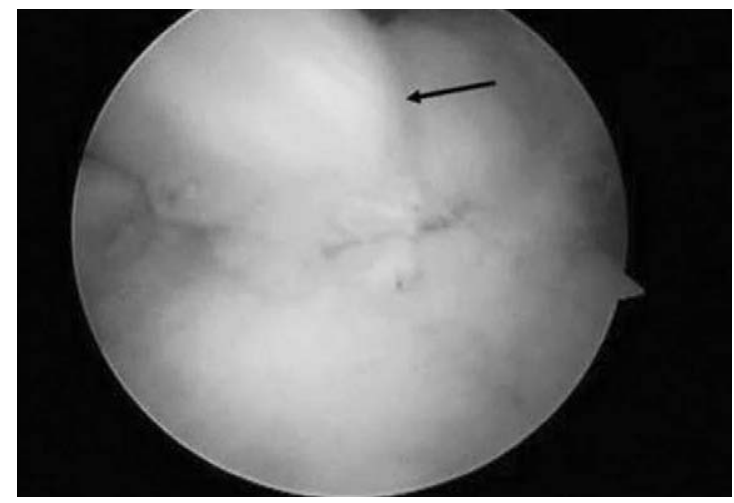

Fig. 3. Biceps tissue is repaired by anchor suture loop (arrow).

tion, motion range, strength and patient's satisfaction. The result was statistically analyzed using SPSS for Windows release 10.0. Data were analyzed by paired Student's t-test, and Wilcoxson signed rank test was adopted for nonparametric variables.

After surgery, final MRI is checked 6 patients out of 14 patients (Fig. 2).

\section{SURGICAL TECHNIQUE}

Surgery was performed on patients under general anesthesia with the lateral decubitus position of 5 patients in the beach-chair position 9 patients.

After identification of the SLAP lesion, the superior rim of the glenoid was debrided by shaver exposing a bony surface.

Biceps tissue was repaired by anchor suture loop (Fig. 3). The tension of the repaired tissue was probed to verify sta- $^{-}$ bility and the need for additional anchors.

\section{RESULTS}

There were 14 patients enrolled in the study. The follow-up time was above 2 
years for all patients. Analysis of results according to the VAS for pain and instability, ADL which is derived from ASES scores and ULCA showed that the scores at final follow-up were significantly improved than those of preoperative scores $(P<0.05)$. The mean UCLA score were pre-operatively 14.4 and post-operative last follow-up 31.2. The mean VAS for pain were 4.9 and 1.0. The mean VAS for instability were 2.6 and 0.5 . The mean ADL were 10.4 and 25.0. 12 patients reported their satisfaction as good to excellent and 10 of the 14 patients returned to their pre-injury level of activity(athletics) $(\mathrm{P}<0.05)$.

We experienced 1 patients of postoperative stiffness of shoulder.

\section{DISCUSSION}

Many studies ${ }^{2.6 .7 .11-13.15 .20 .21)}$ have reported the techniques and results of arthroscopic repair of the unstable SLAP lesion. The SLAP lesion was classified into 4 types by Snyder et $\mathrm{al}^{16)}$ in 1990. In 1995 Maffet et al8) described 3 additional types, such type V, VI, and VII. A type II SLAP lesion is the most common type of labral injury and is reported to comprise approximately $50 \%$ of all SLAP lesions ${ }^{8,16)}$. Morgan et $\mathrm{al}^{10)}$ classified the type II SLAP lesion into 3 types in 1998 based on anatomic location (anterior type II, posterior type II, and combined anterior and posterior type II) ${ }^{9)}$.

Rhee ${ }^{15)}$ described that arthroscopic treatment of unstable isolated SLAP lesions resulted in good or excellent UCLA scores in $86 \%$ of the patients.

Our result is that 12 patients of 14 reported their satisfaction as good to excellent 10 of the 14 patients returned to their pre-injury level of activity.

The conventional knotless suture anchor is a metallic suture anchor (Mitek, Westwood, MA), which was proposed to avoid the need for arthroscopic knot tying ${ }^{17.19)}$. The anchor allow a direct low profile suture, a good capsular shift ${ }^{18)}$, and good bone pullout strength ${ }^{5.19)}$.

The bioabsorbable suture anchor construct also had similar strength over a $12^{-}$ week period of implantation with a comparable metal anchor construct. These absorbable anchors offer a reasonable alternative to metal anchors, with comparable strength and function and advantages unique to an absorbable anchor ${ }^{3)}$.

Although the use of bioabsorbable knotless suture anchors can simplify the technique for arthroscopic SLAP repair and lead to shorter surgical times, the risk for failure still exists ${ }^{22)}$. This procedure minimizes the need of complex suture management and arthroscopic knot tying. It is easily reproducible and appears to allow for a safe and stable repair ${ }^{22)}$.

This current study has several limitations. Imaging study were not done at the time of last follow up to determine the anatomical integrity of the repaired superior labrum except 6 patients. There was no comparison group.

There was no article for clinical result for repair of unstable type II SLAP with bioabsorbable knotless suture anchor yet.

\section{CONCLUSION}

In conclusion, arthroscopic treatment using bioabsorbable knotless suture anchors appears to be a viable alternative to traditional suture anchors to manage 
patients with unstable type II SLAP lesions.

\section{REFERENCES}

1) Andrews JR, Carson WG, McLeod WD: Glenoid labrum tears related to the long head of the biceps. Am J Sports Med, 13: 338-341, 1985.

2) Cohen DB, Coleman S, Drakos MC, Allen AA, O'Brien SJ, Altchek DW, Warren RF: Outcomes of isolated type II SLAP lesions treatend with arthroscopic fixation using a bioabsorbabe tack. Arthroscopy, 22: 136-142, 2006.

3) DeJong LS, DeBerardino TM, Brooks DE, Judson K: In vivo comparison of a metal versus a biodegradable suture. Arthroscopy, 20: 511516, 2005.

4) Ellman H, Hanker G, Bayer M: Repair of the rotator cuff. J Bone Joint Surg Am, 68: 11361144, 1986.

5) Garofalo R, Mocci A, Moretti B, Callari E, Giacomo G, Theumann N, Cikes A, Mouhsine E: Arthroscopic treatment of anterior shoulder instability using knotless suture anchors. Arthroscopy, 21: 1283-1289, 2005.

6) Kartus J, Kartus C, Brownlow H, Burrow G, Perko M: Repair of type-2 SLAP lesions using Corkscrew anchors. A preliminary report of the clinical results. Knee Surg Sports Traumatol Arthrosc, 12: 229-234, 2004.

7) Kartus J, Perko M: The disabled throwing shoulder: spectrum of pathology. Part II: evaluation and treatment of SLAP lesions in throwers. Arthroscopy, 20: 336, 2004.

8) Maffet MW, Gartsman GM, Moseley B: Superior labrum-biceps tendon complex lesions of the shoulder. Am J Sports Med, 23: 93-98, 1995.

9) Mihata T, McGarry MH, Tibone JE, Abe M, Lee TQ: Type II SLAP lesions: a new scoring system-the sulcus score. J Shoulder Elbow Surg, 14: 19-23, 2005.

10) Morgan CD, Burkhart SS, Palmeri M, et al: Type II SLAP lesions three subtypes and their relation to the superior instability and rotator cuff tears. Arthroscopy, 14: 553-565, 1998.

11) Nam EK, Snyder SJ: The diagnosis and treat- ment of superior labrum, anterior and posterior (SLAP) lesions. Am J Sports Med, 31: 798-810, 2003.

12) Nord KD, Masterson JP, Mauck BM: Superior labrum anterior posterior (SLAP) repair using the Neviaser portal. Arthroscopy, 20: 129-33, 2004.

13) Panossian VR, Mihata T, Tibone JE, Fitzpatrick MJ, McGarry MH, Lee TQ: Biomechanical analysis of isolated type II SLAP lesions and repair. J Shoulder Elbow Surg, 14: 529-534, 2005.

14) Research committee, American shoulder and elbow surgeons: Richard RR, An K, Bigliani LU, et al: A standardized method for the assessment of shoulder function. J shoulder Elbow Surg, 3: 347-352, 1994.

15) Rhee YG, Lee DH, Lim CT: Unstable isolated SLAP lesion: clinical presentation and outcome of arthroscopic fixation. Arthroscopy, 21: 1099, 2005.

16) Snyder SJ, Karzel RP, Del Pizzo W, et al: SLAP lesions of the shoulder. Arthroscopy, 6: 274-279, 1990.

17) Thal R: A Knotless suture anchor: Technique for use in arthroscopic Bankart repair. Arthroscopy, 17: 213-218, 2001.

18) Thal R: Knotless suture anchor: Arthroscopic Bankart repair without tying knots. Clin Orthop Relat Res, 390: 43-51, 2001.

19) Thal R: Knotless suture anchor: Design, function, and biomechanical testing. Am J Sports Med, 29: 646-649, 2001.

20) Wilk KE, Reinold MM, Dugas JR, Arrigo CA, Moser MW, Andrews JR: Current concepts in the recognition and treatment of superior labral (SLAP) lesions. J Orthop Sports Phys Ther, 35: 273-291, 2005.

21) Wolf BR, Selby RM, Dunn WR, MacGillivray JD: Lasso repair of SLAP or Bankart lesions: a new arthroscopic technique. Arthroscopy, 20: 125-128, 2004.

22) Yian E, Wang C, Millett PJ, Warner JJP: Arthroscopic repair of SLAP lesions with a bioknotless suture anchor. Tehnical note. Arthroscopy, 20: 547-551, 2004. 


\section{초 록}

목적: 이 연구는 제 2형 SLAP 병변에 대한 생체흡수성 knotless suture anchor의 결과 를 평가하고자 하였다.

대상 및 방법: 단독으로 발생한 제 2 형 SLAP 병변을 가진 14 예의 환자가 관절경 하 생체흡 수성 knotless anchor를 이용하여 수술적 봉합을 시행받았다. UCLA 및 통증에 대한 $\mathrm{VAS}, \mathrm{ASD}$ 가 평가에 이용되었으며, 술 후 추시 최소 2 년째 견관절 검사를 시행하였다.

결과: 평균 27.1 개월의 추시기간 동안 평균 UCLA 점수는 술 전 14.4 에서 최종 추시에는 31.2 로 향상되었다. 통증에 대한 평균 $\mathrm{VAS}$ 점수는 4.9 에서 최종 추시에는 1.0 이었다. 불안 정성에 대한 평균 $\mathrm{VAS}$ 점수는 2.6에서 최종 추시에서는 0.5 였다. 평균 $\mathrm{ADL}$ 은 10.4 에서 최 종 추시에 25.0 이었다. 12 예의 환자가 우수, 우량의 만족도를 보였으나 14 예 중 단 10 예만이 수상 전 운동 범위로 돌아갔다 $(\mathrm{P}<0.05)$.

결론: 생체흡수성 knotless suture anchor를 사용하는 관절경적 봉합술은 단독 제2형 SLAP 병변의 치료에 대해 효과적인 수술 술기이다. 전체 만족도는 단지 $85.7 \%$ 였으며, 게다 가 1 예에서는 심한 강직을, 1 예에서는 활액막염으로 인한 장기간의 견관절 통증을 보였다.

색인 단어: 견관절, 단독 SLAP II, 생체흡수성 knotless suture anchor. 